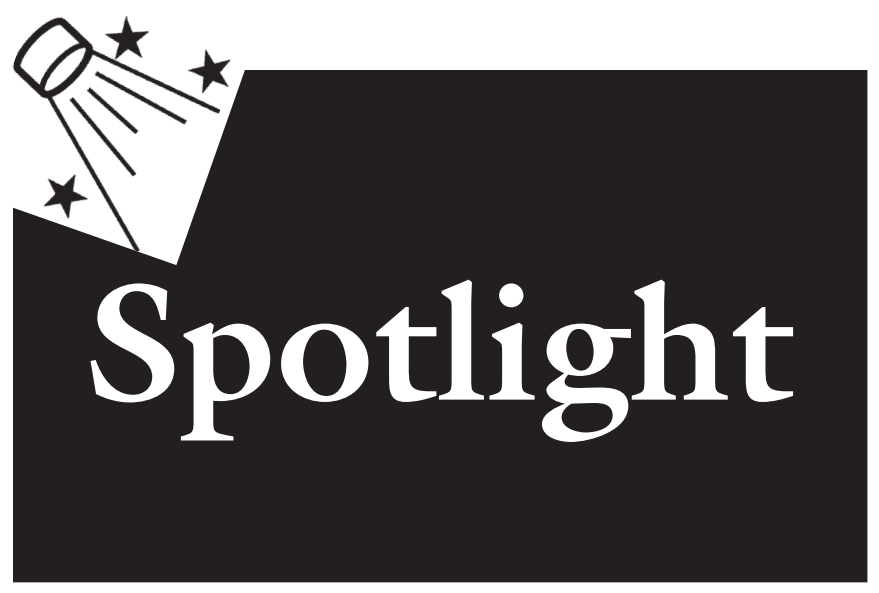

\section{Literature in the Garden Curriculum Effects on Children's Life Skills}

Children's gardens recently have been shown to increase life skills. Fleener et al. (p. 424) assessed the effects that plant activities from the "Literature in the Garden" curriculum have on six children's life skills: teamwork, self-understanding, decision-making, communication, and overall life skills. Third grade students who participated in eight plant activities were compared with control-group students. No significant increases of life skills were found in the experimental group; however, several trends were observed with students who read more for fun, read more each week, and read more garden books generally increasing in life skills.

\section{Performance of Cut Flowers after Shipment to the U.S.}

Cut alstroemeria, carnation, gerbera, and rose were transported via commercial carriers from Bogotá, Colombia, to the U.S. on a monthly basis for 1 year using a 7 -day conventional distribution system with temperature controls and 3-day or 24-hour rapid transport systems with little or no temperature controls, respectively. Leonard et al. (p. 435) found that these transport systems exposed flowers to fluctuating temperatures ranging from 3 to $27^{\circ} \mathrm{C}$. For the majority of shipments, flowers transported using the rapid transport systems had increased vase life compared to those transported for 7 days. Some varieties were more tolerant of the longer transport.

\section{Interactive Tools Developed for an Online Plant Identification Course}

Three interactive teaching tools were developed by Campbell et al. (p. 504) for use by students enrolled in a University of Florida distance education plant identification course. A plant identification quiz used detailed photographs to test students' ability to identify plants taught in class. A leaf terminology quiz was a drag-and-drop tool that asks students to associate specific terms with scanned leaf images. An ecosystem association quiz had students relate native plant selection and landscape performance with photographs of natural Florida ecosystems. These tools provided immediate feedback to students and could easily be modified for use in other horticulture courses.

\section{Three Native Shrubs for Use in Rain Gardens}

Plants in rain gardens typically experience alternating periods of flooding and drying. Dylewski et al. (p. 461) evaluated three native woody landscape shrubs for tolerance to repeated short-term flooding events. Sweetspire, inkberry holly, and possumhaw all maintained growth and good visual quality even when flooded repeatedly for periods as long as 7 days. Additionally, all three species tolerated both quickly draining substrates, which tended to dry out more between flooding events, and more-slowly drying substrates.

\section{Ornamental Grasses Show Minimal Response to Cultural Inputs}

Nine warm season grass species were evaluated in trial gardens at two sites in northern Florida. Thetford et al. (p. 443) observed that only eastern gamagrass, elliott's lovegrass, gulf hairawn muhly, little bluestem, and 'Central Park' maiden grass showed significant responses to cultural inputs of irrigation and fertilization. A high level of survival and acceptable visual quality was evident after two seasons for these five grasses and 'Adagio' maiden grass at both sites, and little bluestem and 'Prairie Sky' and red switchgrass in the westernmost site. 'Hamelin' chinese fountain grass was not an acceptable perennial in either site.

\section{Fall Raspberry Production in Northern Minnesota using High Tunnels}

Yao and Rosen (p.429) evaluated five fall raspberry varieties in the field and in high tunnels for 2 years at Grand Rapids, $\mathrm{MN}$. The average yield $(4.27 \mathrm{lb} /$ plant $)$ in the high tunnel was 2.8 times higher than the yield in the field $(1.12 \mathrm{lb} /$ plant) when the growing season was extended for 4 weeks with the help of a propane burner. 'Polana' and 'Caroline' were the two top-yielding varieties in the high tunnel. Based on the results of this study, fall raspberry can be grown successfully in USDA Zone $3 \mathrm{~b}$ areas using high tunnels.

\section{Growth/Development of Poinsettia in Biodegradable/Compostable Containers}

Lopez and Camberato (p.419) evaluated plastic, rice hull, wheat starch-derived bioresin, molded fiber, straw, coconut coir, composed cow manure, and peat moss and wood pulp containers for production of poinsettia. They found that plastic, rice hull, wheat starch, and molded fiber containers remained unchanged in appearance and integrity through 14 weeks. Although plant quality was not negatively impacted by any of the containers, plants produced in molded fiber containers exhibited the greatest height, bract area index, and total root and shoot weight. 


\section{Cold Chain and Strawberry Quality: From the Field to Retail}

Strawberries have a relatively short shelf life that is strongly impacted by postharvest temperature management practices. Pelletier et al. (p. 482) imposed different precooling treatments on five pallets of fruit that were then shipped from California to Florida. Upon arrival, fruit were exposed to three different retail conditions. Temperatures were monitored throughout the distribution chain and visual quality was evaluated during simulated retail conditions. Results highlight the importance of precooling and show the impacts of partial and delayed precooling on loss of fruit weight and quality.

\section{Botanic Garden Horticulture Improves Plant Conservation Economics}

Palma corcho (Microcycas calocoma) is a highly coveted, difficult to grow, and expensive cycad. It is imperiled in the wild, partly due to removal for sale to collectors.

Kay et al. (p. 474) present a case study of palma corcho history and cultivation at a botanic garden in Florida. In recent years improved propagation methods have greatly increased the supply of palma corcho seeds, and this appears to have reduced the price considerably, thus removing the incentive for poaching and theft. Palma corcho can serve as a model for conservation horticulture.

\section{Altering Irrigation Practices to Reduce Water Use and Maintain Tomato Yields}

An automated tensiometer-based irrigation controller was used by Coolong et al. (p. 466) to impose several irrigation regimes on plasticulture-grown tomatoes. Maintaining soil moisture levels at a constant level, as opposed to allowing soil to dry for long periods of time and then rewetting it, led to decreases in water use while maintaining yields. Similar systems have been successfully used for vegetable crops grown on sandy soils, but little information has been available for such management strategies in fine-textured soils. This information may lead to new irrigation recommendations for vegetable crops. 